\title{
Note on Spelling, Translations, and Currency
}

In conforming to the fluidity of writing in the seventeenth and eighteenth centuries, I have retained all the original spelling and orthography applied to personal names, Jewish institutions, and places located in the ghetto of Modena as I found them in the archival documents I have consulted. For the sake of clarity, when quoting from primary sources, I have adjusted the punctuation to standard modern English. In the case of Hebrew words and expressions written in Latin characters and according to the Italian pronunciation from the seventeenth and the eighteenth centuries, I have transliterated them according to modern standards. Unless otherwise indicated, all translations are my own.

The principal currency used in Modena and the Este Duchy in the period analyzed in the book were the Modenese lira and zecchino. The Modenese lira was a silver coin worth 20 soldi; there were I2 denari per lira. In I600 one Modenese lira was valued at I.5403 Italian lire (plural for lira); in 1639 the value diminished to 0.9242 , and in 1679 to 0.572 I. In the following century, the Modenese lira's value diminished further to 0.3695 in $1739,0.3733$ in 1782 , and 0.3846 in 1796 . The zecchino in circulation since $126 \mathrm{I}$ was valued per Modenese lira as follows: 8 in 1608 , 13 in 1639 , and $37^{1 / 2}$ in 1737 . Unless otherwise specified, in this book the term lira is used for the Modenese lira. Other coins produced by the Ducal Mint and widely circulated were the scudo di Ercole III, scudo di Francesco III, giorgino, sesino, mezza lira, and ducato. The above key information draws on Angelo Martini, Manuale di metrologia, ossia misure, pesi e monete in uso attualmente e anticamente presso tutti i popoli (Turin: Loescher, 1883), 370-73; and Arsenio Crespellani, La Zecca di Modena nei periodi comunale ed estense corredata di tavole e documenti (Modena: Tipi di G. T. Vincenzi e Nipoti, I884), I89-90. 